\title{
Late orogenic intramontane basin development: the Granada basin, Betics (southern Spain)
}

\author{
J. Rodríguez-Fernández and C. Sanz de Galdeano \\ Instituto Andaluz de Ciencias de la Tierra (CSIC-Univ. Granada), Fac. Ciencias, Granada, Spain
}

\begin{abstract}
The quantitative study of subsidence in the Granada basin, using decompaction and backstripping techniques, and contemporaneous relief development in the surrounding areas, especially in the Sierra Nevada, provides a good case example of the development of an intramontane basin. In the Granada basin, according to the interpretation of the seismic profiles and results of the backstripping analysis, subsidence and sedimentation rates were at a maximum in the late Tortonian and decreased progressively; meanwhile, the neighbouring areas were uplifted forming important relief. Chronostratigraphical revisions of the marine sediments show that the marine incursion that deposited sediments in the Granada basin lasted only 1.3 Ma, between 8.5 and 7.2 Ma. The gradual retreat of the sea in the Granada basin is not attributable to global eustatic fluctuations, but rather to uplift in the Sierra Nevada and its adjacent areas. From latest Tortonian to early Messinian times, the region became continental and the Granada basin acquired its present physiography and was differentiated as such. From the late Tortonian onwards, NNW-SSE compression combined with ENE-WSW extension affected the cordillera. In the Granada basin, extension controlled fault movements. There are two well-defined fault sets: the first trends $70^{\circ} \mathrm{N}-90^{\circ} \mathrm{E}$, with low angle faults (less than $30^{\circ}$ ) dipping towards the north and south, defining the subsiding areas which have approximately $\mathrm{E}-\mathrm{W}$ direction; whereas the second set has a NW-SE direction, and cuts and displaces the previous ones, defining the main subsiding areas in the eastern part of the basin. The reinterpretation of seismic profiles reveals that the subsiding axes within the Granada basin persisted from the Tortonian to the present because of continued displacements of the main faults.
\end{abstract}

\section{INTRODUCTION}

The relationship between the formation of relief and the late stages of mountain belt development is well established, particularly in the case of Alpine chains such as the Himalayas, Andes, Alps, Betics or the Aegean area (Gansser, 1982; ten Veen \& Posma, 1999a, b) owing to extensional, transcurrent or transtensional mechanisms, depending on the case. More recently, researchers have undertaken the quantification of vertical displacements in sedimentary basins as well as in the surrounding relief, for instance in the Mediterranean Sea and its peripheral chains (Ryan, 1976; ten Veen \& Postma, 1999a, b). The Betic Cordillera is not an outsider to these studies, and different techniques of analysis have been used in order to quantify its vertical displacements (Giménez et al., 2000; Braga et al., 2003; Sanz de Galdeano \& Alfaro, 2004).

Not many models have been proposed to explain the formation of the Granada basin. Rodríguez-Fernández et al. (1989) emphasize the role of strike-slip faulting and un-

Correspondence: J. Rodríguez-Fernández, Instituto Andaluz de Ciencias de la Tierra (CSIC-Univ. Granada), Fac. Ciencias, 18071 Granada, Spain. E-mail: jrodrig@ugr.es. derline the coincidence of many patterns with that of pullapart basins. The coexistence of compressional and extensional deformation as a consequence of strike-slip faults is also described by Morales et al. (1990).

The quantitative analysis of subsidence of the sedimentary sequences filling the basins, based on backstripping and decompaction techniques, has likewise been applied to different geologic domains of the Betic Cordillera, such as the continental margins (Janssen et al., 1993; Watts et al., 1993; Geel, 1995; Hanne et al., 2003) in the Alboran Sea (Cloetingh et al., 1992; Banda et al., 1993; Rodríguez-Fernández et al., 1999), or in its intramontane basins (Soria et al, 1998, 2001; Rodríguez-Fernández et al., 1999). Whereas the analysis of the whole process of subsidence combined with the formation of relief is commented on by a number of authors, to date no comparison and numeric analysis of the two processes has been documented.

The Granada basin is situated at the western foot of the Sierra Nevada and is one of the main intramontane basins formed during the late orogenic stage in the Betic Cordillera. It is probably the most complex basin of the Betic Cordillera, where noteworthy thicknesses of detritic sediments were deposited from end Miocene to PlioceneQuaternary times. The Sierra Nevada presents the highest 
peaks of the Betic Cordillera (3482 m), formed from the late Miocene onward, whose slopes preserve late Miocene marine sediments, up to nearly $1900 \mathrm{~m}$ a.s.l. A comparison of the Granada basin and the Sierra Nevada enables us to characterize and quantify the processes of subsidence and uplift, in a context similar to that of other Alpine chains.

A sound knowledge of the main stratigraphic and sedimentologic characteristics of the Granada basin - together with the existence of 29 seismic profiles, one borehole, and gravimetric data from oil research - allowed us to reinterpret the structure of the basin and quantify the subsidence as well as reconsider the geodynamic evolution of the ba$\sin$. The recent evolution of the relief can also be quantified and compared with the subsidence inferred from previous and our own data. To this aim, we reinterpret seismic profiles from the northern and central part of the basin. They were digitized to derive basement contour maps, and for the first time we establish:

(1) isopach maps of the different sedimentary sequences, constructed to identify the morphology of different depocentres and changes in their location and form;

(2) maps showing fault location, differentiating between those that affect the basement, the sedimentary infilling, or both;

(3) subsidence analysis, quantifying the sediment accumulation rates $\left(\mathrm{m} \mathrm{Ma}^{-1}\right)$ for different ages and sectors of the basin;

(4) chronologic revision of the marine sediments, through new studies of the palaeontological contents of several cross sections, as well as a better knowledge of the evolution of the quantified processes.
With these analyses, the final objective of this work was to assess subsidence in the Granada basin and uplift of the relief in the surrounding areas, determining how and when these processes occurred, in the framework of the geodynamic mechanisms involved in the late Neogene evolution of the Betic Cordillera.

\section{GEOLOGICAL SETTING}

The Betic Cordillera is, together with the Rif, the westernmost Alpine mountain belt that surrounds the Mediterranean Sea. It is made up of the external zone to the north and the internal zone to the south. The external zone (Fig. 1) corresponds to the mesozoic and tertiary sediments of the Iberian palaeomargin and is divided into Prebetic and Subbetic domains, the latter now located further to the south.

The internal zone comprises three tectonically superimposed complexes that are, from the base to the top: the Nevado-Filabride, the Alpujarride and the Malaguide. The Nevado-Filabride and Alpujarride are strongly affected by Alpine metamorphism. The internal zone was displaced westwardly at the beginning of the Miocene until colliding with the external zone, especially with the Subbetic, and was then strongly deformed (Durand-Delga, 1980; Sanz de Galdeano, 1990). Several phases of extensional tectonics during the early to middle Miocene and up to the beginning of the late Miocene contributed to denuding the internal zone, resulting in the exhumation of the previously superimposed complexes (Balanyá \& García-Dueñas, 1987; Monié et al., 1991; García-Dueñas et al.,

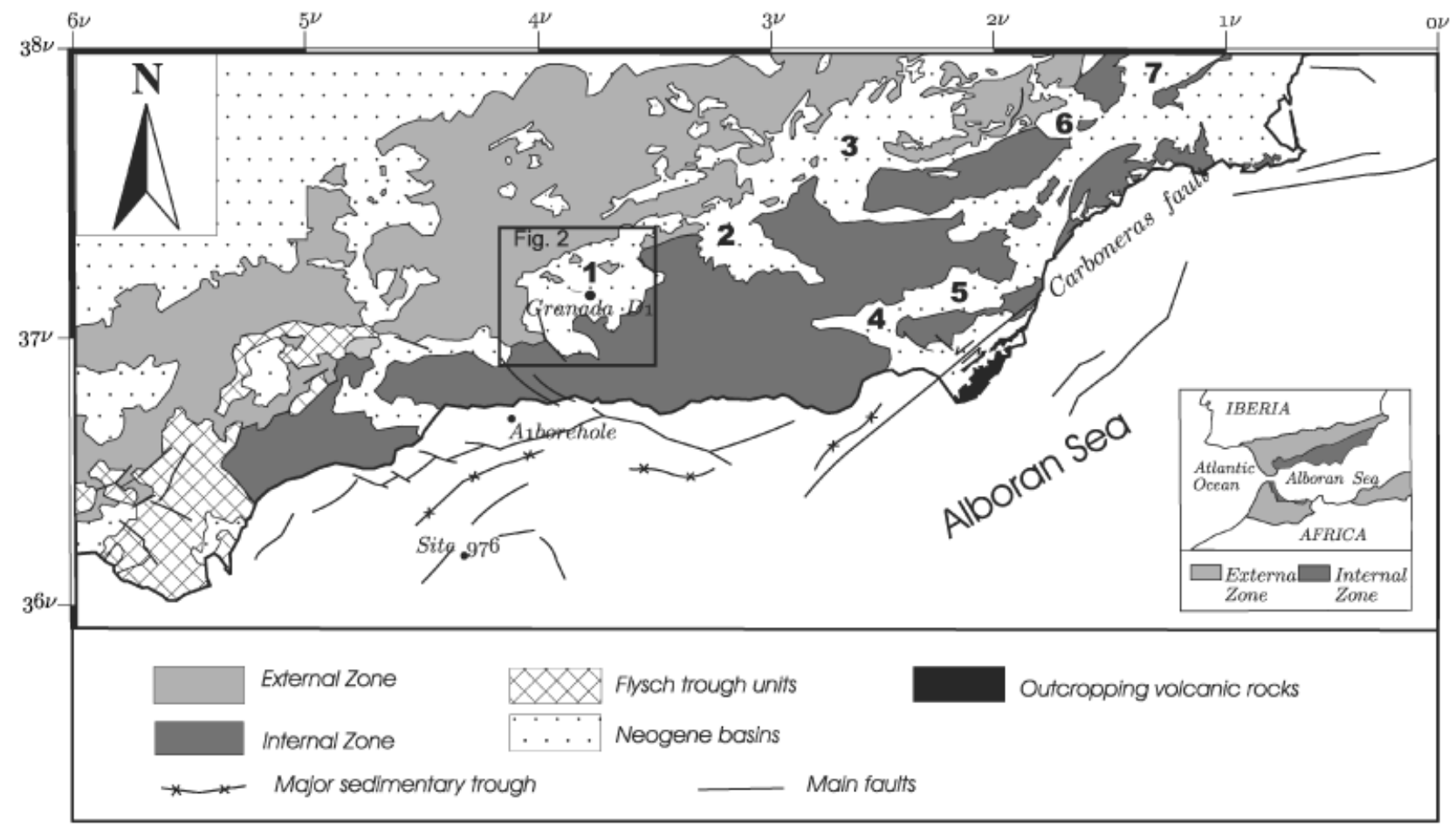

Fig. 1. Location of the Granada and other Neogene basins in the Betic Cordillera. 1. Granada basin, 2. Guadix basin, 3. Baza basin, 4 . Tabernas basin, 5. Sorbas basin, 6. Lorca basin, 7. Fortuna basin. 
1992; Watts et al., 1993; Platt \& Whitehouse, 1999). Finally, from the late Tortonian, a NNW-SSE compression combined with a near perpendicular extension affected the Betic Cordillera (Sanz de Galdeano, 1988; RodríguezFernández \& Martín-Penela, 1993; Galindo-Zaldívar et al., 1993, 1999; Buforn et al., 1995), facilitating the progressive exhumation of the Nevado-Filabride complex (the deepest of the three) between 12 and $8 \mathrm{Ma}$ (Johnson et al., 1997).

Unconformably deposited on the Subbetic, Alpujarride and Malaguide complexes are sediments of early and middle Miocene age, representing the remains of previous sedimentary basins that were later destroyed. During the late Miocene new basins formed, including those of Guadix, Baza, Lorca, Fortuna and that of Granada (Fig. 1), covering part of the contact between the internal and external zones.

These basins have a series of common stratigraphic characteristics: the presence of evaporites deposited in the latest Tortonian and therefore before the 'Messinian salinity crisis' of the Mediterranean (Rodríguez-Fernández et al., 1984; Garcés et al., 1998; Dinarés et al., 1999), an important accumulation of coarse clastic sediments located at the foot of prominent reliefs, and finally, fresh-water lacustrine deposits at the end of the late Miocene. These characteristics provide evidence of a relatively rapid uplift and growth of relief at the end of the late Miocene (Montenat et al., 1990).

Previously, during the middle Miocene to the early Tortonian, the region was subjected to a tectonic denudation process (Johnson et al., 1997) that did not produce important relief and did not contribute to the formation of intramontane basins.

The creation of relief and the subsidence of associated sedimentary basins is strongly influenced by the reactivation of old faults and the appearance of new ones in a context of reorganization of the cordillera (Sanz de Galdeano \& Alfaro, 2004), as a consequence of the collision between Africa and Europe from the late Tortonian.

\section{THE SEDIMENTARY RECORD OF THE GRANADA BASIN}

The basement of the Granada basin is formed by metamorphic rocks of the internal zone (in the southeastern half) and sedimentary rocks of the Subbetic (in the northwestern half) of the Betic Cordillera, together with early and middle Miocene sedimentary remnants of older Neogene basins (Fig. 2). In the present paper, these sediments are considered to form part of the basement.

The Granada basin filling has a markedly molassic character (Van Houten, 1981). Three depositional sequences can be distinguished:

\section{Sequence 1}

It contains marine sediments of late Tortonian age lying unconformably on the basement (Fig. 2). The transition from coastal to platform conditions (Fernández \& Rodríguez-Fernández, 1991), testifying the sudden flooding of
theTortonian sea, is observed in several places, for example in the southwestern part of the basin, in the town of Alhama de Granada, an exceptional deepening upward sequence is preserved.

The upper Miocene sedimentation began with bioclastic calcarenites, deposited in an epiric sea with temperate waters that change distally to calcareous marl facies. Near the emergent high relief areas of the basement, the facies are apron type, corresponding to the base of ancient cliffs, whose sediments comprise large blocks or conglomerates with a calcarenitic matrix. Overlying the previous sediments are found:

- Along the eastern border, fan deltas, fed by a drainage network that developed in adjacent relief and deposited thick accumulations of conglomerates. They evidence the important growth of relief, particularly along the eastern border.

- The western and southern borders of the basin were sites of carbonate sedimentation with a platform where coralline reefs developed. Similar reefs colonized fan delta topsets. This change in sedimentation indicates a confinement of the basin, which began to lose its connection to the open sea, as a result of the onset of uplift of the entire region (Rodríguez-Fernández et al., 1984; Montenat et al., 1990; Braga et al., 1999). Such uplift is compatible with the data presented by Johnson $(1993,1997)$ and Johnson et al. (1997), who, from apatite and zircon fission track, date the cooling of the Nevado-Filabride complex near the surface at 9-8 Ma in the western Sierra Nevada area, when the tectonic denudation ceased. These authors indicate that 'tectonic events at that time, which resulted in the initial structuration of the intramontane Betic basins and development of the modern topography, are somehow linked to this change'

The base of marine sequence 1 contains the planktonic foraminifer Neogloboquadrina humerosa (Blom) and the discoasterid Discoaster quinqueramus (Gartner). Bearing in mind that the biohorizon of the first appearance of both is located at $8.5 \mathrm{Ma}$ (Okada \& Bukry, 1980; Berggren et al., 1995), the marine incursion would have this age as the maximum. Discoaster quinqueramus (Gartner) is present in the top of sequence 1, whereas the Globorrotalia suterae zone (Okada \& Bukry, 1980; Iaccarino, 1985), the latest Tortonian, is absent; therefore the age of the top of this sequence is situated in the 'non-terminal late Tortonian', before the Tortonian-Messinian boundary (7.12 Ma).

\section{Sequence 2}

This sequence overlies sequence 1 (Fig. 2), conformably in the centre and unconformably at the edges of the basin. It was deposited in a continental environment and varies in character and nature depending on location. The deposition of thick evaporitic deposits (gypsum and salt) in the southern part of the basin signals the final retreat of the sea. 


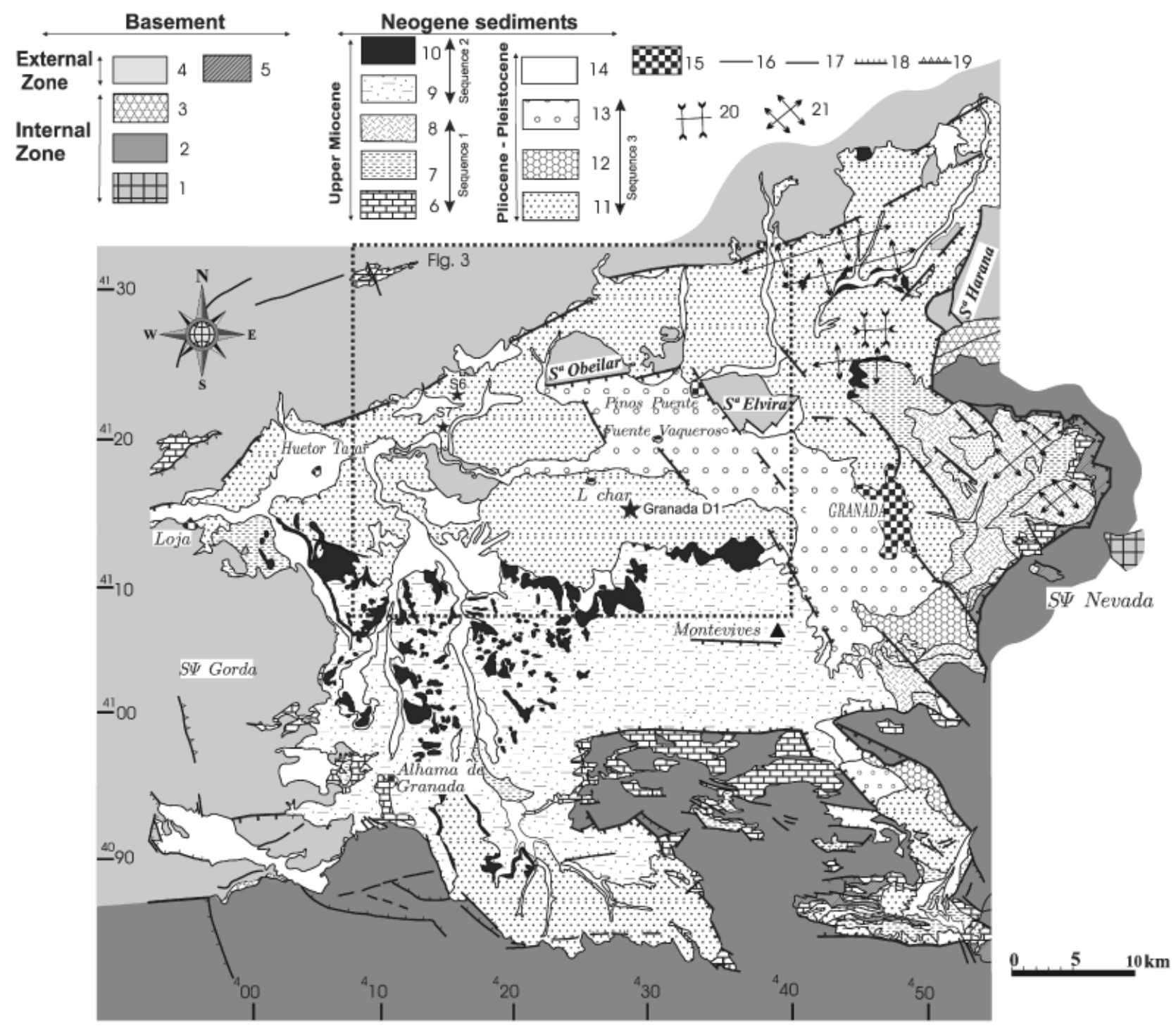

Fig. 2. Geological map of the Granada basin. 1. Nevado-Filabride complex, 2. Alpujarride complex, 3. Malaguide complex, 4. Subbetic, 5. Marls, sands and conglomerates (Serravallian-Early Tortonian), 6-8: sequence 1, 6. calcarenites (late Tortonian), 7. Marls and conglomerates (lateTortonian), 8. conglomerates, sands and marls (lateTortonian ), 9 and 10: sequence 2, 9. marls, silts, sands and gypsum (Messinian), 10. Lacustrine limestone (late Messinian), 11-13: sequence 3, 11. conglomerates, sands and clays (Pliocene-Pleistocene), 12. Alluvial fans (Pleistocene-Holocene), 13. Alluvial plain (Pleistocene-Holocene), 14. Alluvial sediments (recent), 15. town, 16. lithological contact, 17. fault, 18. normal fault, 19. reverse fault, 20. syncline, 21. anticline. The position of the figure is marked in Fig. 1. The square dotted line marks the area covered by seismic lines (Fig. 3). The stars correspond to the boreholes cited in the text.

In the Sierra Nevada footslopes and in the northeastern Sierras, coarse clastic sediments were deposited by large alluvial fans in identical positions to those occupied by the fan deltas of the previous sequence. These alluvial fans evolved into a braided river system that deposited sands and micaceous silts, and then into several deep lakes, some containing thick lacustrine turbiditic deposits (Dabrio et al., 1972).

These facies of fine micaceous sands and silts contain the first fossil records of lacustrine environments in the Granada basin. They are micromammalian rodents (Occitanomis adroveri, Ruscinomis schaubi and Valerymys juniensis) that point to the NM12 zone - of late Turolian age, equivalent to latest Tortonian in the marine chronology - for the lower part of sequence 2 (Dabrio et al., 1978; Ruiz-Bustos, 2002).
Overlying the previous succession, terrigenous sediments were deposited by braided rivers sourced from surrounding high relief areas. These rivers fed into lakes located in the deepest parts of the basin. In the lakes, fine-detrital, marly and calcareous sediments, featuring thin lignite levels, were deposited (Dabrio \& Fernández, 1986). These lacustrine sediments contain a rich vertebrate fauna that point to a latest Ventian age for the top of sequence 2, equivalent to Messinian in continental chronology (Ruiz-Bustos, 2002). The second sequence culminates with the deposition of lacustrine limestones (Fig. 2).

Because the bottom of sequence 1 is late Tortonian in age (8.5 Ma, Discoaster quinqueramus zone) and the bottom of sequence 2 is latest Tortonian in age (7.2 Ma, NM12 zone), 
the marine incursion that deposited sequence 1 would correspond to a time span ranging between 8.5 and $7.2 \mathrm{Ma}$, not lasting more than $1.3 \mathrm{Ma}$.

\section{Sequence 3}

A new network of braided rivers developed in the shallow areas of the basin, and lacustrine zones in the more depressed areas (Fig. 2). Sediment consists of: conglomerates, sands and clay of fluvial origin for the fluvial facies; and sand, silts, lignite and limestones for the lacustrine facies. This endorheic phase lasted until the late Pliocene. The considerable thickness of the sediments (over $1000 \mathrm{~m}$ in some places) is clearly inferred from the seismic lines. The Pliocene sediments are dated indirectly with respect to the Miocene-Pliocene boundary at their base and the early Pleistocene at their top (Ruiz-Bustos, 2002).

In the Pleistocene, the basin was captured by the drainage network of the Guadalquivir River. From this time onward, a longitudinal fluvial system (the Genil River, tributary of the Guadalquivir River) developed, whose flood plain is the present alluvial plain of Granada.

The important high relief created along the eastern border of the basin was drained by alluvial fan systems. Some formations deposited at the end of the Miocene were eroded and redeposited during the Pleistocene.

A borehole (Granada D-1) located near Lachar (LA) (Figs 3, 4, 6, 7 and 10) penetrated $834 \mathrm{~m}$, revealing from bottom to top: a basement of Subbetic character $(233 \mathrm{~m})$, marly limestone sediments of middle Miocene age $(21 \mathrm{~m})$, calcareous marls of Tortonian age $(73 \mathrm{~m}$, corresponding to sequence 1), marly-sandy-silty sediments with gypsum and lacustrine limestones of late Miocene age (Ventian; $253 \mathrm{~m}$, sequence 2), ending in detrital sediments of Pliocene-Pleistocene age ( $254 \mathrm{~m}$, correlated with sequence 3$)$. The three sequences differentiated in the borehole may be easily correlated with those described above. One of

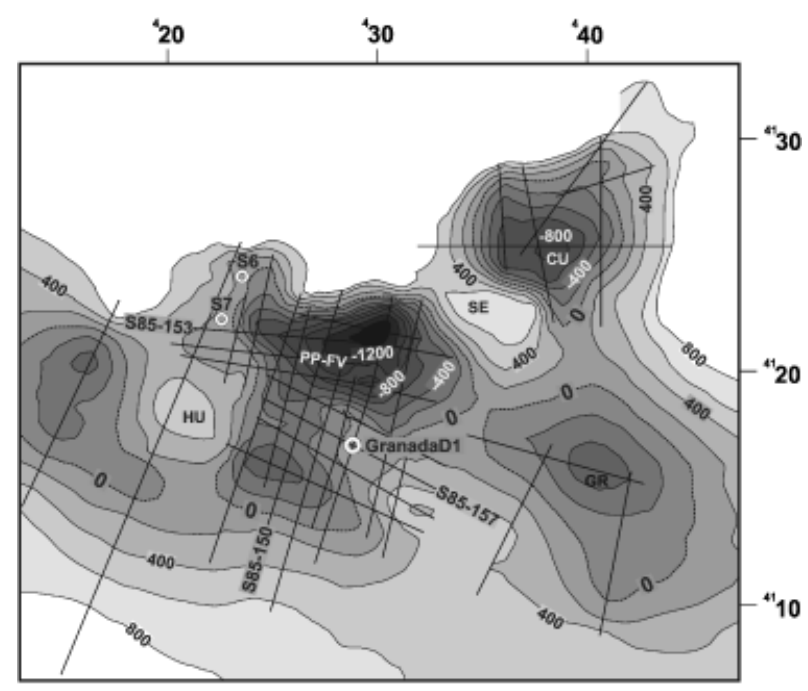

Fig. 3. Contour map of the area covered by the 29 reinterpreted seismic lines showing the location of Granada D-1 borehole and $\mathrm{S} 6$ and $\mathrm{S} 7 \mathrm{mining}$ holes. Their positions are indicated by the square dotted line of Fig. 2. the seismic profiles (S85-157) (Figs 3, 4 and 10) passes over this borehole, although nearby there are two short boreholes for mining research (S6 and S7, Fig. 3). On the basis of data from the Granada D-1 borehole and knowledge of the depth of each of the three main seismic reflectors (described in the next chapter) we calculated the seismic velocity, used later to transform the seismic time (TWT) into depths. These velocities also were used to elaborate the maps and cross sections, and in the numeric analyses of the data. The crossing of different seismic profiles, always with the help of the seismic facies, permitted the identifi cation of the main reflectors that bound the differentiated sedimentary sequences.

\section{SEISMIC STRATIGRAPHY}

In the seismic profiles (Figs 3-5), the three depositional sequences can be recognized, separated by prominent reflectors. The clearest reflectors correspond to:

1. The contact between the basement and the sedimentary fill of the basin, coinciding with the base of sequence 1 . The basement shows a homogeneous character with reflectors of low continuity and medium-high amplitude, and a non-strata pattern can be identified. Some more prominent reflectors are difficult to identify and interpret.

2. Reflector 2 corresponds to the boundary between marine and continental sediments of late Miocene age. Between sequences 1 and 2 in the deepest parts of the basin, the paraconformity between the reflectors of the two sequences demonstrates that the transition from marine to continental sedimentation took place without erosion in these deep parts (Fig. $4 a$ and b). In the seismic profiles, the continental sediments of the late Miocene (sequence 2) appear as a homogeneous unit without internal discontinuities, with continuous and very marked reflectors of middle amplitude that clearly onlap the basement highs.

3. Reflector 3 represents the boundary between the continental sediments of late Miocene and Pliocene age, that is, between sequences 2 and 3. The continental sediments of late Miocene age contain, toward the top, lacustrine limestone levels of Ventian (Messinian) age. These levels usually exhibit good contrast and a continuous reflector with high amplitude whose upper limit coincides with the base of the continental sediments of the Pliocene-Pleistocene (Estévez et al., 1982).

Within the Pliocene-Pleistocene sequence, some well marked reflectors with low continuity and high amplitude exist. Toward the top, recent alluvial and colluvial sediments are present, yet not well distinguished because of their minor thickness.

The seismic profiles were used to prepare contour maps of the basement as well as isopach maps (Fig. 9), and to draw several cross sections (A-D, Fig. 8) of the different depositional sequences. To obtain the isopach maps we used 

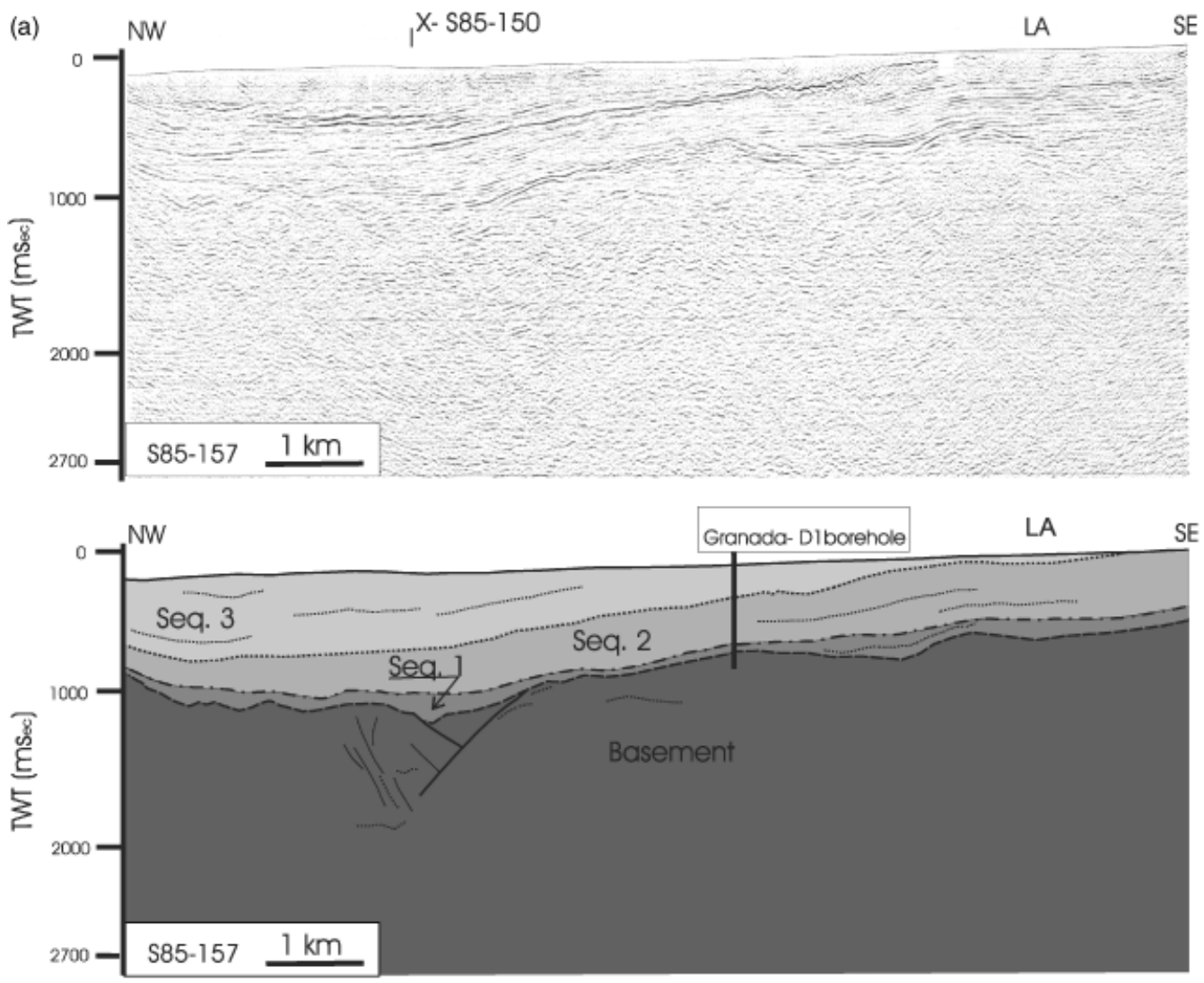

(b)
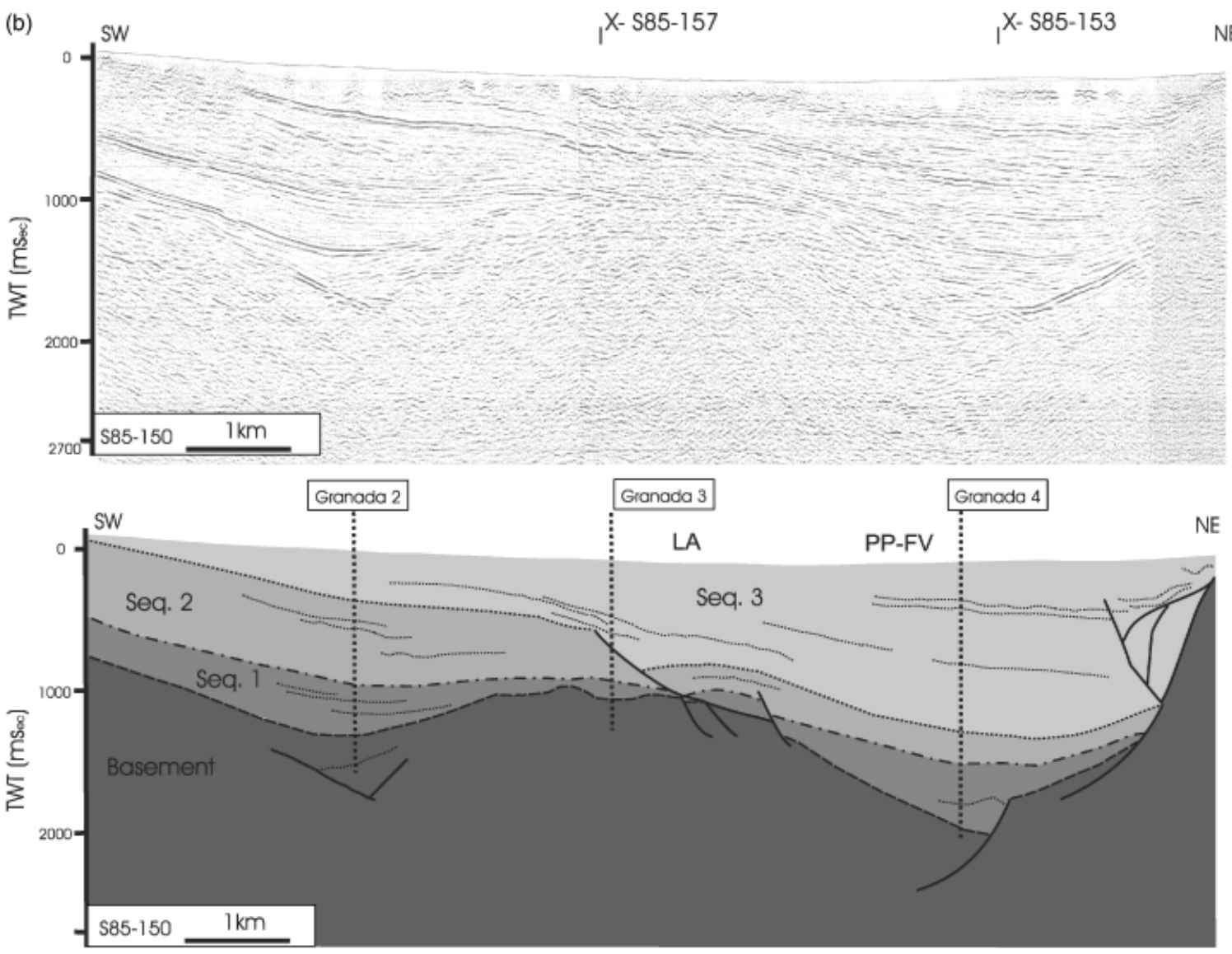

Fig. 4. Interpretation of part of seismic profiles S85-157 and S85-150. Their positions are marked in Fig. 3. Vertical dotted lines correspond to the selected places for backstripping analysis. LA, Alto de Lachar; PP-FV, Pinos Puente-Fuente Vaqueros depocentre. The cross points between profiles are indicated. 

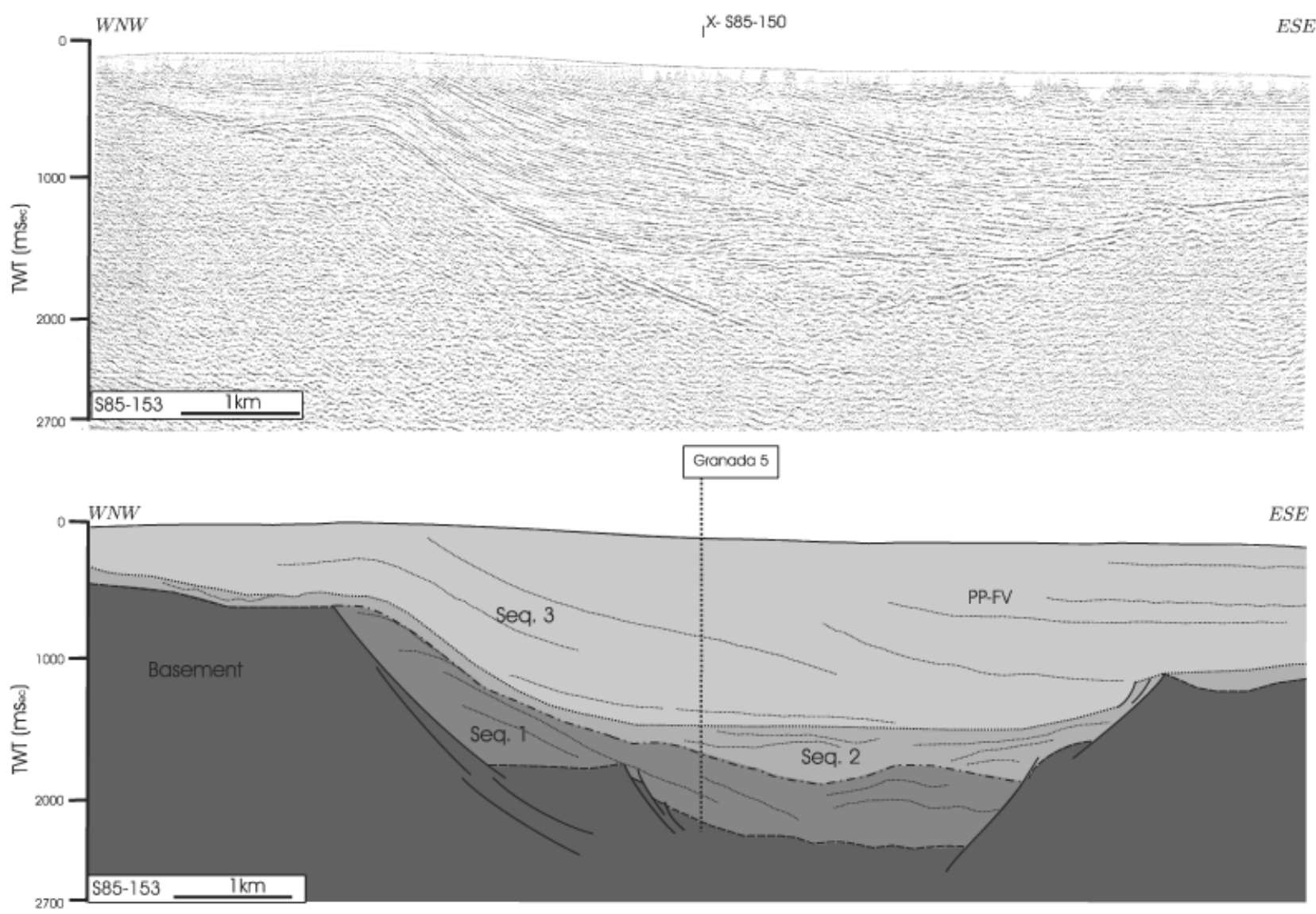

Fig. 5. Interpretation of part of seismic profile S85-153. Its position is marked in Fig. 3. Vertical dotted line corresponds to the selected place for backstripping analysis. PP-FV, Pinos Puente-Fuente Vaqueros depocentre. The cross point with profile S85-150 is indicated.

the position and the depth of the shot points along the seismic lines. Depth was previously derived from the velocity deduced from seismic time and comparison with the depth of reflectors in the Granada D-1 borehole. The next step was to plot these points using a GIS programme to construct the different maps. Vertical sections obtained from the seismic profiles (Granada 2 to Granada 5), and data from borehole Granada D-1 were used for the decompaction study to calculate subsidence rates (Figs 4, 5 and 10).

\section{BASIN ARCHITECTURE}

Sedimentation in the Granada basin was controlled by several sets of normal faults, most notably those of E-W and NW-SE direction. Many of these faults are identified by surface mapping (Figs 2 and 7). In sectors not covered by the seismic lines, important faults also crop out. These are clearly visible to the south of the basin, where they have an $\mathrm{E}-\mathrm{W}$ trend and dip northwards.

Conspicuous NW-SE faults are present in the eastern part of the basin, some of which limit the Granada basin (Figs 2 and 7). NNE-SSW trending faults are also present on the eastern border of the basin and limit the western part of the Sierra Nevada. They are not observed within the basin. The combined throw of the NW-SE and NNE-SSW faults along the western border of the Sierra
Nevada is up to $5000 \mathrm{~m}$. In comparison, the combined throw of the NW-SE faults along the western border of Sierra Elvira (SE) is estimated to be of the order of $2000 \mathrm{~m}$. These NW-SE faults cross-cut and displace previous $\mathrm{E}-\mathrm{W}$ faults, defining the main subsiding areas of the central and eastern part of the basin.

The Bouguer gravity map of the Granada basin (provided by Chevron Oil Company) (Fig. 6a) and the contour map of its basement, obtained by the seismic profile grid of the area they cover (Fig. 6b), show that within the basin there are several more subsident sectors where significant negative gravity values occur (down to $-130 \mathrm{mgal}$ ) along with other uplifted sectors (with gravity values up to -110 mgal). The general structure is illustrated in Figs 4-8. It consists of:

- The structural high (Alto de Lachar (LA)), where the thickness of the sediments is reduced, bounded by low angle normal $70^{\circ} \mathrm{N}-90^{\circ} \mathrm{E}$ trending faults and limiting the southern border of the subsiding sectors of Huetor Tajar (HU) and Pinos Puente-Fuente Vaqueros (PP-FV). The HU sub-basin has a limited subsidence.

- The PP-FV sector, where, in addition to the late Miocene sediments, Pliocene-Pleistocene sediments of considerable thickness - up to $1250 \mathrm{~m}$ - are deposited directly upon the basement in some places (Fig. 8, cross sections A-D). The subsidence implied by the 


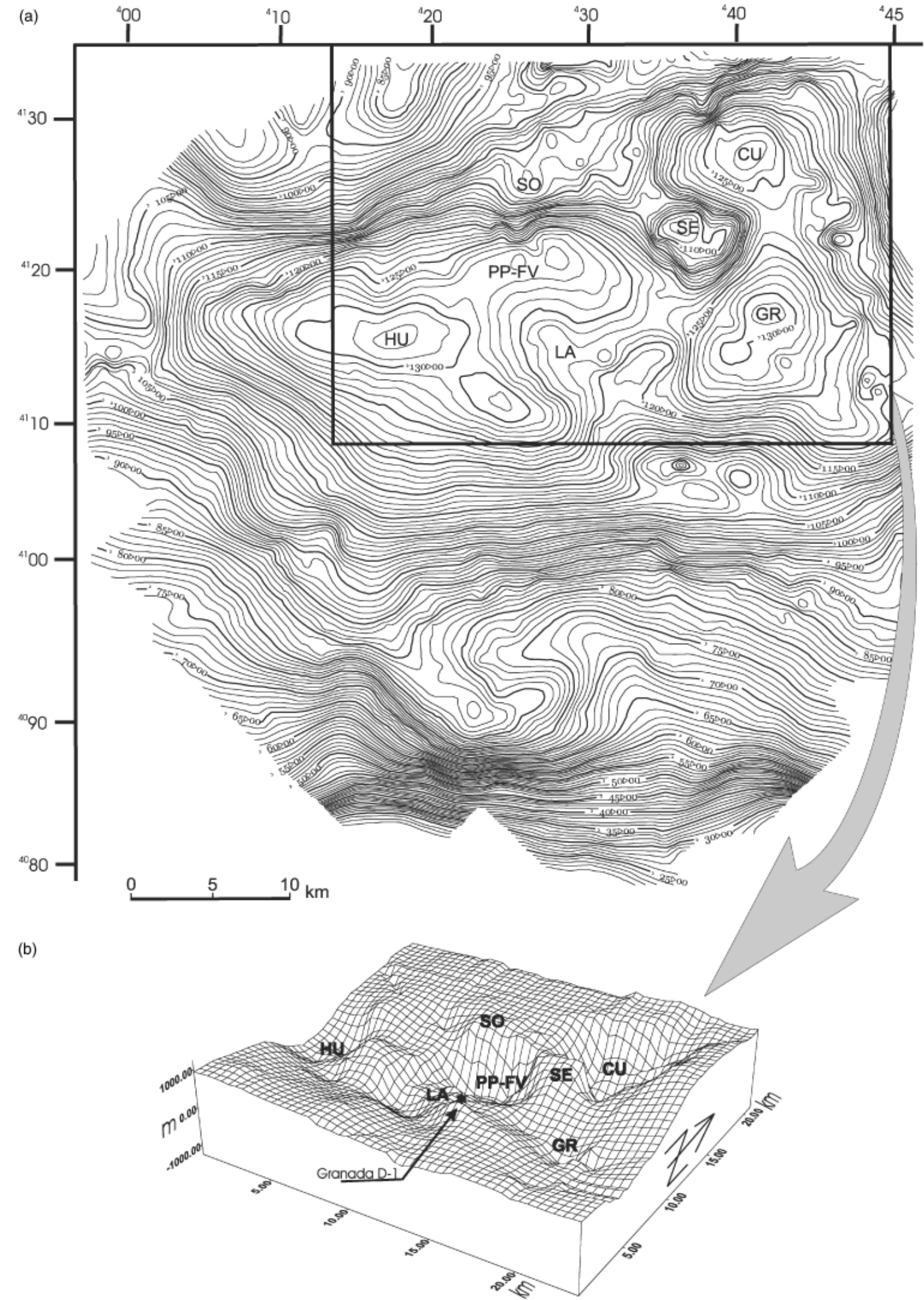

Fig. 6. (a) Bouguer anomaly map of the Granada basin (density reference $2.438 \mathrm{~g} \mathrm{~cm}^{-3}$, supplied by Chevron Oil Company. (b) Threedimensional block of the basement in the area marked in (a), showing the prominent elevated and depressed areas in the basement. Black star corresponds to the location of Granada-D1 borehole. CU Cubillas; GR, Granada; HU, HuetorTajar; LA, Lachar; PP-FV, Pinos Puente-Fuente Vaqueros; SO, Sierra de Obeilar. Note the good agreement between (a) and (b). 


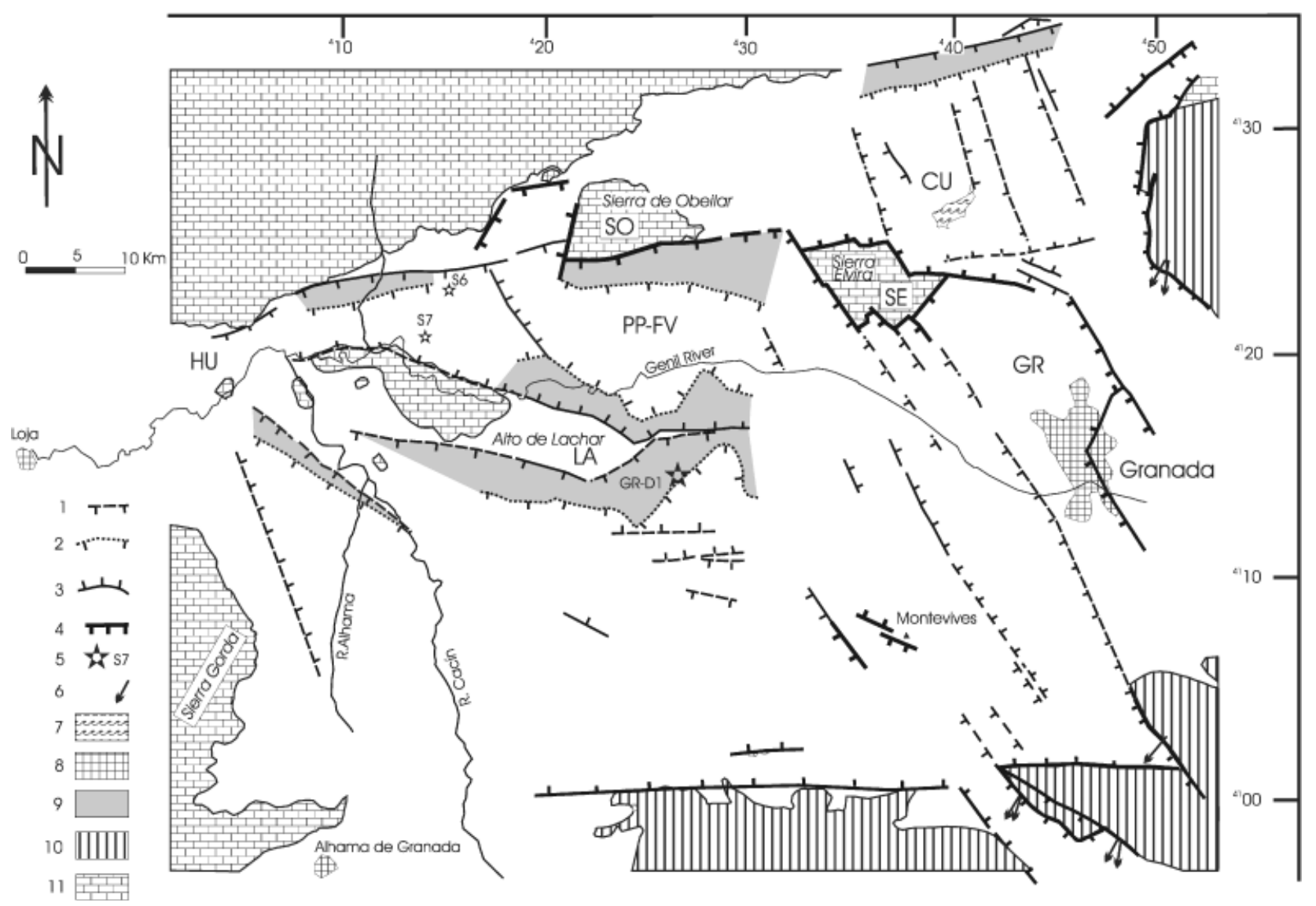

Fig. 7. Map of main faults in the Granada basin. 1. Supposed fault, 2. lower boundary of fault plane, 3. deduced fault from seismic lines, 4. outcropping fault, 5. borehole, 6 . trend of Neogene extension within the basement, 7. dam, 8. town, 9. fault plane at depth, 10. internal zone, 11. external zone.

thickness of sediments was directly controlled by the action of the faults that bound this area. Its northern and eastern borders are limited by $\mathrm{E}-\mathrm{W}$ and NW-SE faults that, at least at the surface, show a high angle $\left(60^{\circ}\right)$. The eastern border corresponds to the complex horst of SE.

- To the southeast of SE, another subsiding sector exists, located in the vicinity of Granada and limited by NW-SE faults (section C, Fig. 8).

- The Cubillas area (CU), to the east of SE, limited by NW-SE and E-W normal faults, is also an important subsiding area (section A, Fig. 8).

In the isopach maps obtained from the seismic profiles (Fig. 9), the marine sediments of late Tortonian age (sequence 1) already show a pattern of graben and horsts with WNW-ESE direction. In the map of sequence 2 (continental sediments of late Tortonian-early Messinian age) the same pattern is seen, but with a greater extension of the sediments. The CU and Granada (GR) depocentres are accentuated, with a smoothing at the Pinos PuenteFuente Vaqueros (PP-FV) depocentres. A smoothing of the horst of LA is also observed.

The isopach map of the Pliocene-Quaternary sediments shows the maintenance of the main horsts and the initiation of a graben, located somewhat more to the $\mathrm{N}$, that connects the depocentres of HU, PP-FV and GR. The CU depocentre becomes smoother during this phase and maintains its position.

In general, the depocentres coincide with the axes of the most subsident areas inside the basin. Only in the easternmost part of the basin, at the foot of the Sierra Nevada, do the depocentres not coincide with these axes. This seems to be a consequence of the volume of sediments supplied by the adjacent high relief areas that result in the great thickness of the fan deltas of sequence 1 .

In summary, the different subsiding areas show a strong asymmetry owing to the displacement of the low angle WNW-ESE faults, as well as those of NW-SE direction. The persistence over time of the location of the depocentres and topographical axes is interpreted as a result of the successive reactivation of the faults.

Fold structures in the Granada basin are present in two well differentiated areas (Fig. 2). The first corresponds to the eastern border of the Sierra Nevada, where NE-SW folds that affect only the sediments of sequence 1 are unconformably overlain by sequence 2 . The second area is CU (Fig. 2), where ENE-WSW very open folds are found to affect the whole sedimentary infill. These folds are attributed to a regional NNW-SSE compression, combined with a nearly perpendicular extension. 

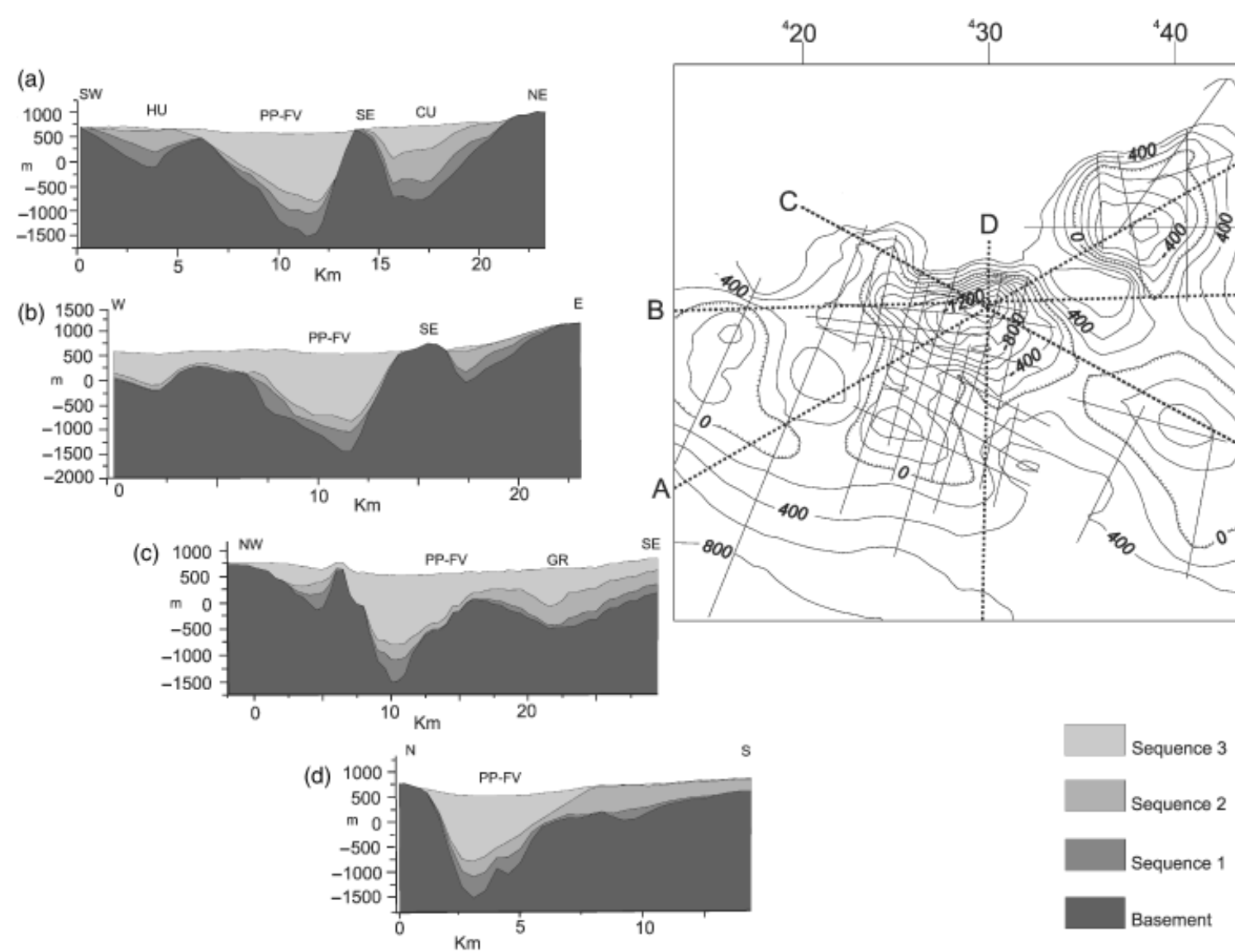

Fig. 8. Sections, obtained from seismic profiles, showing the morphology of the Granada basin and the infilling sedimentary sequences. Zero metres correspond to the present sea level. The different grey shades are equivalent to those of Figs 4 and 5. Location of sections A-D can be seen in the annexed contour map.

\section{SUBSIDENCE ANALYSIS AND SEDIMENTATION RATES}

To calculate subsidence we used the backstripping programme of Allen \& Allen (1990), which calculates total and tectonic subsidence of the basement for decompaction of the differentiated sedimentary sequences. The programme assumes a model of airy-type isostasy. The tectonic subsidence is calculated eliminating the effect of the sediment load.

The values of the density and porosity of the sediments were taken from the standard value charts of Sclater \& Christie (1980). Palaeobathymetric corrections were not applied, given the continental character of most of the sediments; nor were palaeoeustatics, given the minor range of sea level variation for the age of the marine sediments (see Hardenbol et al., 1998).

To estimate the thickness of the sedimentary fill, starting from the seismic profiles, we took an average speed of $1.9 \mathrm{~km} \mathrm{~s}^{-1}$. The stages that were differentiated coincide with the sedimentary sequences, and their chronological limits are: $8.5 \mathrm{Ma}$ for the beginning of the marine incursion; 7.2 Ma for the transition from marine to continental sedimentation; and 5.3 Ma for the Miocene-Pliocene boundary.
For the calculation of subsidence values, five points were chosen (Fig. 10), three of them along the S85-150 profile, and two of them at the cross points with the profiles S85-153 and S85-157, almost perpendicular to the first one. The other two points are located somewhat to the east of the above profiles. One of these points corresponds to the Granada D-1 borehole, where the sediment thickness is known and was used by Rodríguez-Fernández et al. (1999).

Points Granada D-1 and Granada-3 are situated in the LA, whereas the three remaining (Granada-2, -4 and -5 ) are in the depocentres located to the north and south of the LA. In this way the subsidence can be analysed both in the deepest areas and in the relative highs inside the basin.

The calculations of tectonic subsidence and total subsidence (the sum of tectonic subsidence plus that due to the sediment load) are shown in Fig. 10. Points 1 and 3, in the LA, show moderate values of subsidence during the Tortonian and Pliocene-Pleistocene, and slightly greater ones during the Messinian. Point 2, located near HU, shows an important phase of subsidence during the Miocene that subsidence decreases during the Pliocene-Pleistocene, with a value lower than that of LA. Points 4 and 5 exhibit relative subsidence during deposition of sequence 1 (marine sediments of Miocene age) that decreases during the 

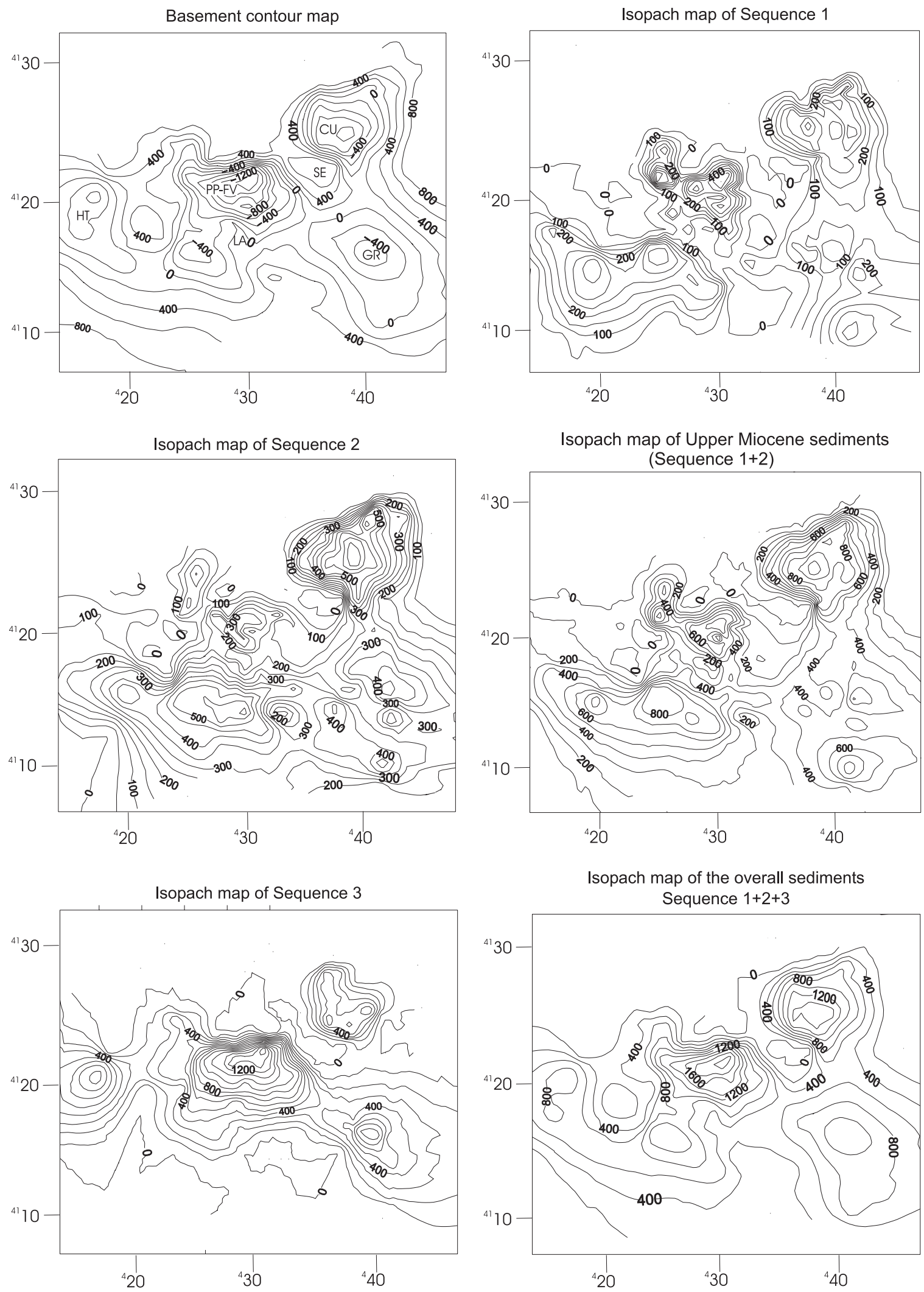

Fig. 9. Contour and isopach maps (in metres) of the basement and the sedimentary infilling of the Granada basin, obtained in the area covered by seismic lines.

phase of lacustrine sedimentation, then increases during the Pliocene-Pleistocene. The values of tectonic and total subsidence, as well as the sedimentation rates for the different sedimentary sequences, are given in Table 1.
The total data obtained from the application of the backstripping programme are indicated in Table 1 . Subsidence is generally shown to reach a maximum in sequence 1 , then to progressively decrease during the Messinian 

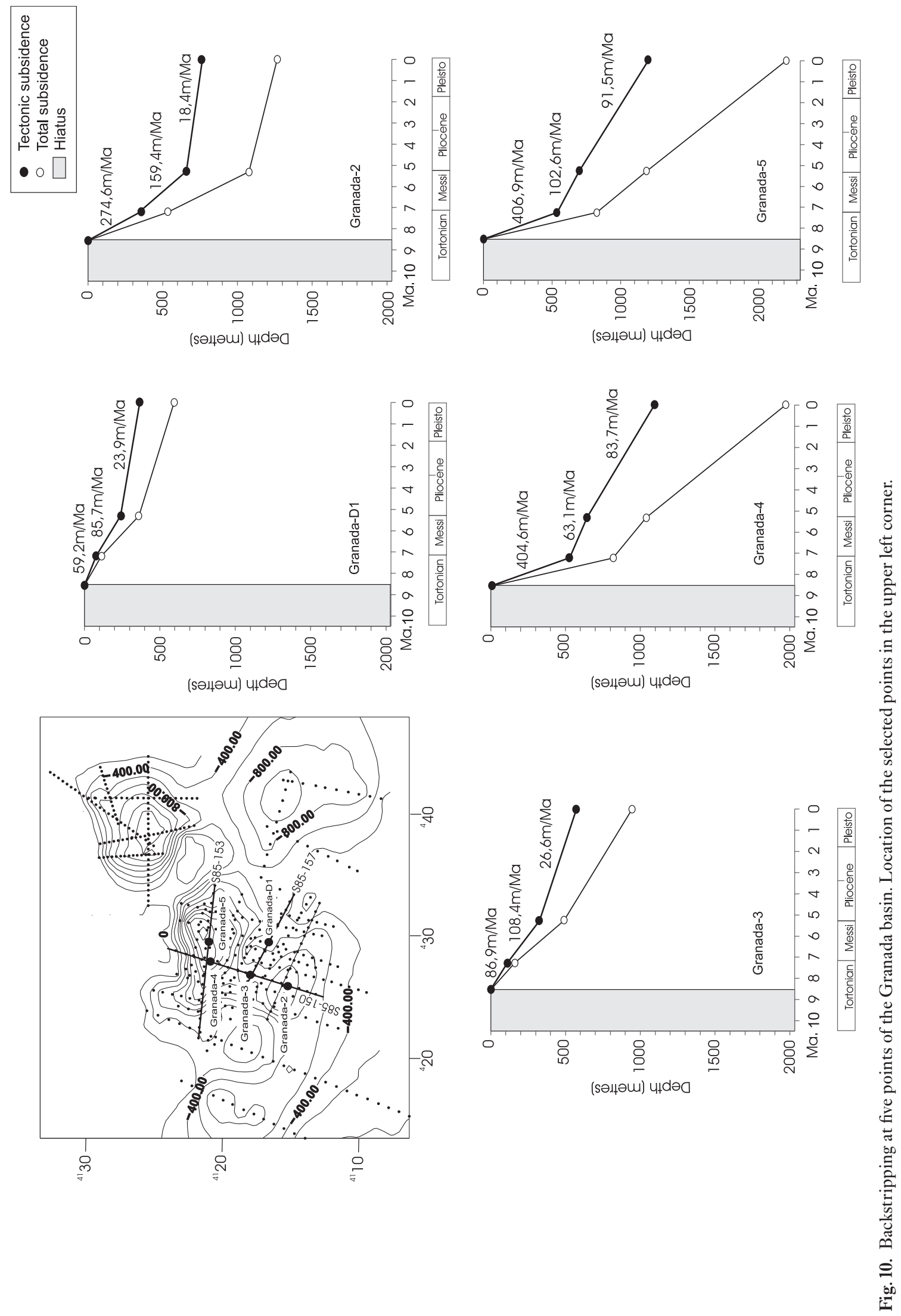
Table 1. Subsidence and sedimentation rates in several points in the Granada basin $\left(\mathrm{m} \mathrm{Ma}^{-1}\right)$

\begin{tabular}{|c|c|c|c|c|c|c|c|c|c|}
\hline \multirow[b]{2}{*}{ Site } & \multicolumn{3}{|c|}{ Tectonic subsidence rates } & \multicolumn{3}{|c|}{ Total subsidence rates } & \multicolumn{3}{|c|}{ Sedimentation rates } \\
\hline & SEQ1 & SEQ2 & SEQ3 & SEQ1 & SEQ2 & SEQ3 & SEQ1 & SEQ2 & SEQ3 \\
\hline Granada D1 & 59.2 & 85.7 & 23.9 & 83.0 & 133.6 & 41.3 & 83 & 142.6 & 47.9 \\
\hline Granada 2 & 274.6 & 159.4 & 18.4 & 410.0 & 287.3 & 35.8 & 410 & 357.3 & 50.9 \\
\hline Granada 3 & 86.9 & 108.4 & 26.6 & 123.0 & 172.6 & 86.4 & 123 & 189.4 & 101.8 \\
\hline Granada 4 & 404.6 & 63.1 & 83.7 & 623.0 & 116.8 & 174.9 & 629.2 & 170 & 225.8 \\
\hline Granada 5 & 406.9 & 102.6 & 91.5 & 633.0 & 195.2 & 193.9 & 633 & 272.6 & 251.3 \\
\hline Average & 217.4 & 102.6 & 44.8 & 329.1 & 176.4 & 99.3 & 374.8 & 226.3 & 135.5 \\
\hline
\end{tabular}

(sequence 2) to the Pliocene-Pleistocene (sequence 3). A similar process is observed with the sedimentation rates during sequence 1 , where the subsidence rate exceeds sedimentation. During deposition of sequences 2 and 3 , the sedimentation rates are slightly higher that those of subsidence mainly in the depocentre of PP-FV.

The previous values for subsidence are based on an understanding that the Granada basin remained stable, which is not the case, since it has risen remarkably, though less than the surrounding areas. The obtained values therefore indicate only the absolute displacements. At the same time, the basin contains several sectors where strong sinking took place, in some cases more than $1000 \mathrm{~m}$. This sinking was controlled mainly by $\mathrm{E}-\mathrm{W}$ and NW-SE faults.

The topographical height of the Granada D-1 borehole is $640 \mathrm{~m}$ and the basement is $580 \mathrm{~m}$ deep, that is, about $60 \mathrm{~m}$ above the present sea level. During the deposition of the marine sediments (sequence 1), the basement was nearly $250 \mathrm{~m}$ deep, according to its facies. The sum of basement depth and posterior local tectonic subsidence were compensated by regional uplift.

To the southeast, in the Sierra Nevada foothills, marine deposits of late Miocene age are preserved at an altitude of 1830 m (Sanz de Galdeano \& López Garrido, 1999) (Fig. 12). To the east, in Sierra Harana, they reach a height of $1623 \mathrm{~m}$, resting on a surface that dips toward the east. Values a little lower can be measured at other points to the north and south of the Granada basin. On the whole the region has risen, though the Granada basin has not risen as much (Fig. 12), some of its basement areas being $1500 \mathrm{~m}$ below the present sea level.

\section{DISCUSSION}

The Betic Cordillera has experienced important uplift from the late Miocene, whereas at the same time intramontane basins have formed in a contemporary process of relief- and basin creation. Reviewing the regional data, the lateTortonian marine sediments are not limited to the current Granada basin, but extend much further; hence, for this time period, we cannot refer to the existence of the basin as such. Inside the basin some positive relief areas existed, such as the highs of SE, LA and Obeilar (SO), along with subsiding areas such as HU, CU and GR.
At the end of middle Miocene the more prominent reliefs of the Betic Cordillera did not yet exist, although their creation was underway. This is evidenced by the coarse detritic character of late Serravallian-early Tortonian sediments, revealing the growth of relief exposed to erosion. They are sediments of a continental character, nourished from the upper complexes of the internal zone (Malaguide and Alpujarride), yet they do not contain clasts derived from the lower complex, the Nevado-Filabride (Rodríguez-Fernández, 1982). In the Tortonian, the topographically lowest areas of the region were subjected to marine incursions, the most important of which taking place in the late Tortonian (at $8.5 \mathrm{Ma}$ ). The short range of the eustatic variations (less than $45 \mathrm{~m}$ in the curve of Hardenbol et al., 1998) for this time span do not explain the marine incursion in the region. Rather, it must be due to subsidence as a consequence of faulting; similar features are described by ten Veen \& Postma (1999a, b) in Crete, Greece. The deposition of marine sequence 1 corresponds to the cited main marine incursion, when the Granada basin registered its highest values in tectonic subsidence $\left(217 \mathrm{~m} \mathrm{Ma}^{-1}\right)$ and the highest sedimentation rates $(374.8 \mathrm{~m}$ $\mathrm{Ma}^{-1}$; Table 1).

The gradual decrease in water depth, a result of regional uplift, culminated in evaporite deposition (gypsum and salt) in the marginal parts of the southern half of the basin. This represents the progressive and definitive retreat of the sea. However, the sheet of water was not lost at its deepest parts, as is evidenced in the seismic profiles, where a paraconformity is observed between sequences 1 and 2 .

The progressively reduced bathymetry of the basin caused a change in the chemical quality of waters that went from marine to brackish, and finally to freshwater, as demonstrated by the sediment facies and fossil record (Dabrio et al., 1972). During the time that marine sedimentation took place in the Granada basin, the level of the ocean fell only $10 \mathrm{~m}$, according to the eustatic curve of Hardenbol et al. (1998). In contrast, decompaction analysis of sediments (Fig. 10), shows that the tectonic subsidence varies from area to area, roughly between 150 and $500 \mathrm{~m}$ (even more in some points). Therefore, the gradual retreat of the sea in the Granada basin is not attributable to global eustatic fluctuations but rather to regional uplift.

The onset of the important uplift of the region concurs with the end of the tectonic denudation (Johnson, 1993, 
1997; Johnson et al., 1997); their data evidence the rapid cooling of the Nevado-Filabride Complex (105$200{ }^{\circ} \mathrm{C} \mathrm{Ma}^{-1}$ ) near the surface at $12 \mathrm{Ma}$ in the eastern part of Sierra Nevada, and at $9-8 \mathrm{Ma}$ in the westernmost part, next to the Granada basin. Uplift clearly began at this time.

In fact, from the late Tortonian, the Sierra Nevada underwent significant uplift while sequence 1 was deposited in Granada basin, whose eastern border has been notably uplifted and preserved in several small outcrops in the slopes of Sierra Nevada (Fig. 12). This sequence reveals, for the first time, pebbles inherited from the Sierra Nevada core (Dabrio et al., 1978; Rodríguez-Fernández, 1982; Sanz de Galdeano \& Vera, 1992). During the process of regional rising, the area occupied by the Granada basin and other proximal sectors was disconnected from the sea, then underwent continental sedimentation that continued to infill the subsiding areas.

In the Messinian-Pliocene passage, a new tectonic phase began, characterized by activity on NW-SE trending faults. Movement along these faults, together with activity on other sets, defined the Granada basin physiography. At the same time, some areas inside the basin began to sink and show a high sedimentation rate $\left(135.5 \mathrm{~m} \mathrm{Ma}^{-1}\right)$, such as the $\mathrm{PP}-\mathrm{FV}$ area, where these movements continue to the present. The abundant seismicity and especially microseismicity (Sanz de Galdeano et al., 2003) that marks the position of the NW-SE faults and the thickness of the accumulated sediments (more than $1000 \mathrm{~m}$ ) support this interpretation.

Presently, the faults that form the eastern border of the Granada basin bound the Sierra Nevada and the Sierra Harana located to the NE. The difference in heights resulting from these faults is substantial, with the Granada basin over $1000 \mathrm{~m}$ lower than the Sierra Harana and over $2500 \mathrm{~m}$ lower with respect to Sierra Nevada. The Sierra Gorda marks the western border of the Granada basin, whose sediments onlap it.

In order to quantify the regional uplift and subsidence that formed the sedimentary basins, the following approach was used (Fig. 11): From the present day height of Tortonian marine sediments, located in the adjacent and more eastern mountains, we subtracted the present benchmarks of the Messinian and Pliocene sediments; and from those of Messinian age, the heights of the Pliocene sediments. In this way the successive heights of deposition are restored, all the sedimentation having occurred in an environment of shallow bathymetry (Braga et al., 2003). This is represented in terms of their age.

The difference between the lowest point in the basement of the Granada basin and the highest in the Sierra Nevada is of the order of $5000 \mathrm{~m}$ (Fig. 12). This difference reflects the magnitude of uplift, as well as of subsidence of the basin, where sedimentary sequences accumulated at the foot of the newly created high relief areas. This involved contemporaneous rising/subsidence and erosion/ sedimentation processes, similar to the ones described by Gansser (1982) for some of the main Alpine chains.

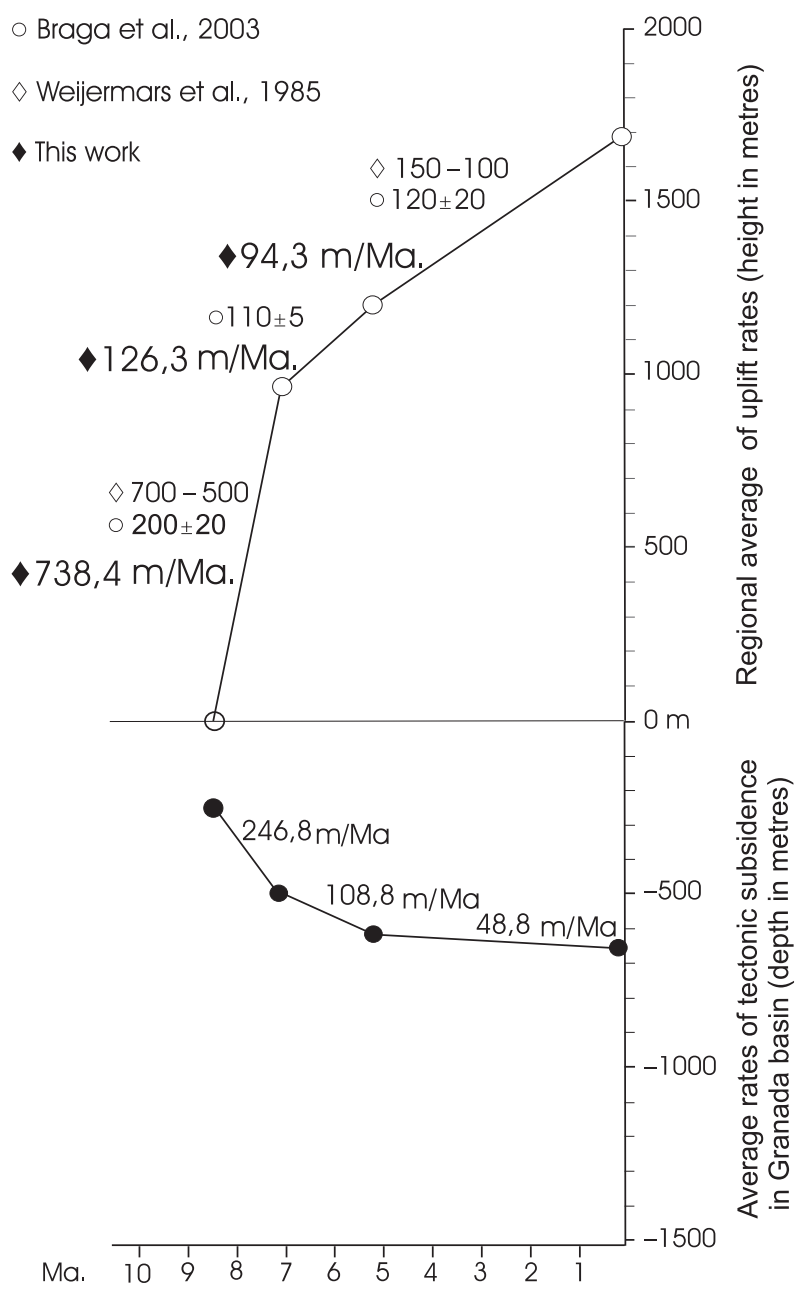

Fig. 11. Relation between the regional average uplift rates and the average rates of tectonic subsidence in Granada basin (a palaeobathymetric correction of $250 \mathrm{~m}$ was applied) obtained in this work and compared with those of Wiejermars et al. (1985) (data from east of Almería) and Braga et al. (2003) (data from east of Sierra Nevada and west of Almería).

Uplift rate was at a maximum in the late Tortonian, with values of $700 \mathrm{~m} \mathrm{Ma}^{-1}$, and diminished in the Messinian and more so in the Pliocene. The average value of the uplift rate (considering only $1700 \mathrm{~m}$ of uplift of the marine Tortonian sediments in the slopes of Sierra Nevada and a time span of $8.5 \mathrm{Ma}$ ) was $200 \mathrm{~m} \mathrm{Ma}^{-1}$ for the recent morphogenetic stage of the cordillera after the final cooling of the metamorphic rocks of the Nevado-Filabride complex. This is the lowest possible estimation.

The above data allow us to conclude that the subsidence and uplift rates were at their maxima in the Tortonian and decreased over time thereafter. Both processes are parallel to the decrease in sedimentation rates, intimately linked to relief creation and erosion. The sedimentation rates in the intramontane Granada basin are similar to those registered in the Alboran Sea, which leads us to surmise that this process was taking place on a regional scale. The data presented here support those published by previous authors, e.g. Wiejermars et al. (1985) and Braga et al. (2003). 


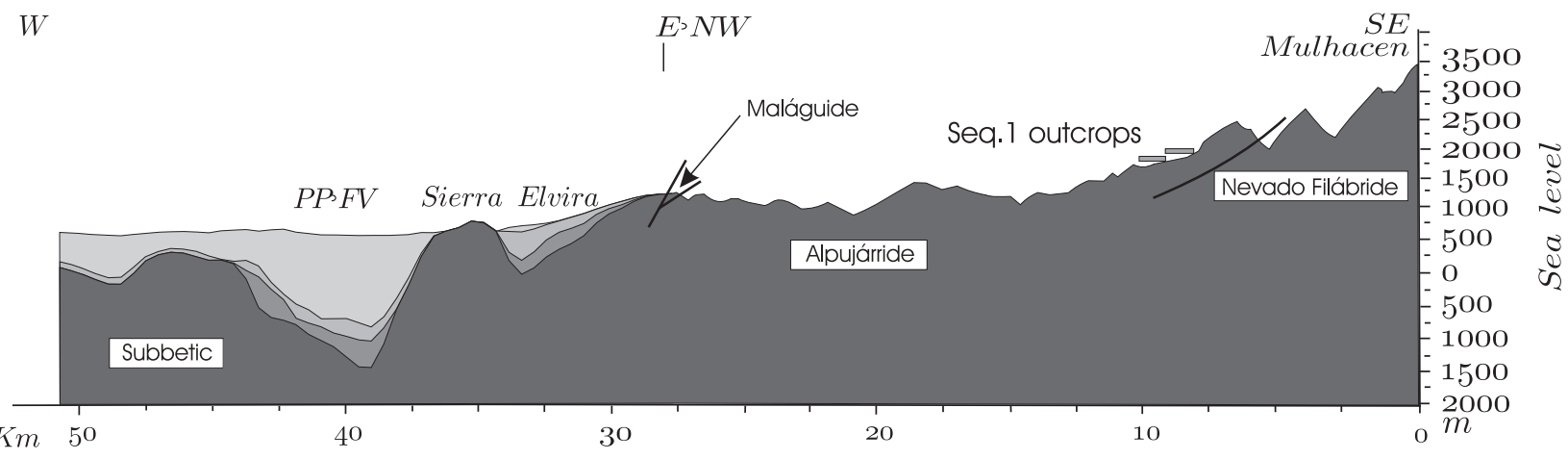

Fig. 12. Section across the Sierra Nevada and Granada basin, indicating the complex distribution in the internal zone as well as the main tectonic contact in between. The different grey shades are equivalent to those of Figs 4, 5 and 8 . Vertical scale is enhanced.

In the Alboran Sea, as in the Granada basin, after a stratigraphic gap, sedimentation was renewed at $8.5 \mathrm{Ma}$ (late Tortonian). The Messinian sediments are scarce and linked to an important unconformity on a regional scale; whereas the sediments of Pliocene and Pleistocene age are represented by thick marly deposits with discontinuities at different heights of the sections. The same occurs in the Granada basin, where subsidence and sedimentation rates decrease from the Tortonian to the Pliocene-Pleistocene (Rodríguez-Fernández et al., 1999).

From a tectonic point of view, the situation in the Alboran Sea was very similar, with a compressive stage combined with a near perpendicular extension in the late Tortonian that produced a readjustment of the whole basin and the reactivation of old faults in a transcurrent regime (Zahn et al., 1999). This readjustment compartmentalized the basin and enhanced structural features, such as the Alboran High. During this time some strike-slip faults, including the Carboneras fault (Fig. 1), continued offshore (Rodríguez-Fernández \& Comas, 1999).

The rising of the region is very substantial, yet differs from place to place. The Sierra Nevada summit rose of the order of $5000 \mathrm{~m}$ in relation to some points of the basement of the Granada basin that straggled behind. These rising and sinking movements were facilitated by the displacement of the faults described.

Finally, other analyses of subsidence in the Betic Cordillera likewise demonstrate that during the late MiocenePliocene the basins located in the Internal Zone and the Valencia trough underwent important subsidence and uplift processes (Janssen et al., 1993; Soria et al., 1998, 2001; Hanne et al., 2003).

The previous data draw a geodynamic scenario in which the Granada basin was formed by tectonic subsidence because of cortical stretching. Very briefly, the proposed scenario is:

During the middle Miocene to the early Tortonian, the internal zone of the Betic Cordillera was affected by tectonic extension that produced subsidence, thereby facilitating the marine invasion that occurred in the late Tortonian ( $8.5 \mathrm{Ma})$. In the Granada basin, this subsidence was more active in the depocentres controlled by $70^{\circ} \mathrm{N}$ $90^{\circ} \mathrm{E}$ faults. At the end of the Tortonian, the situation chan- ged because the approximately north-south convergence between Africa and Iberia was renewed (Sanz de Galdeano, 1988; Galindo-Zaldívar et al., 1993, 1999; Rodríguez-Fernández \& Martín-Penela, 1993; Buforn et al., 1995; Rodríguez-Fernández \& Comas, 1999; Sanz de Galdeano \& Alfaro, 2004). From this time, NNW to $\mathrm{N}-\mathrm{S}$ compression was established in the Betics and the Alboran basin, combined with an important, and nearly perpendicular, extension. This compression produced antiforms in the internal zone (Galindo-Zaldívar et al., 2003; Sanz de Galdeano and Alfaro, 2004). The uplift of several areas, including Sierra Nevada itself, was contemporaneous with subsidence in Granada and other neighbouring intramontane basins. This process, enhanced by the displacement of NW-SE faults in Granada basin, continues up to the present. According to the previous data, the documented influence of extensional faults, combined with the subsidence history, we interpret that the Granada basin is an intramontane basin driven by extension, perpendicular to the NNW-SSE compression, linked to the tectonic denudation of the surrounding areas.

\section{CONCLUSIONS}

As a result of reinterpreting the seismic profiles of the Granada basin, revising the micropalaeontological content of the marine sediments and processing and quantifying all the available numeric parameters, we arrive at the following conclusions, some of them put forth for the first time:

The marine incursion that deposited sequence 1 can be delimited in time from 8.5 to $7.2 \mathrm{Ma}$ - that is, lasting only 1300000 years. During this time the Granada basin was part of another more extensive basin. The retreat of the sea in the Granada basin is not attributable to global eustatic fluctuations but rather to vertical readjustment of the basement as a consequence of the rising of Sierra Nevada and its adjacent areas. At the beginning of PliocenePleistocene times, the Granada basin acquired its current physiography.

During the late Tortonian, a NNW-SSE direction compression and an ENE-WSW extension are registered. This 
extension is clearly present in the Granada basin, and has controlled the sense of fault displacement. The persistence of the depocentres and subsidence axes in an identical position during the deposition of several sequences is inferred to be the result of the repeated displacements of the main faults.

The faults observed in the seismic profiles have the same directions as those that crop out at the borders of the basin. In general, two well-defined sets are observed, the first showing $\mathrm{N} 70-90 \mathrm{E}$ direction, with fault planes slightly dipping toward north and south that define the main subsiding areas of approximate $\mathrm{E}-\mathrm{W}$ direction. The second set, with a NW-SE direction, cuts and displaces the previous ones and defines the main subsiding areas of the eastern part of the basin.

Subsidence was at a maximum in the late Tortonian, decreased in the Messinian and was even less in the Pliocene-Pleistocene. A similar process is observed with the sedimentation rates: during sequence 1 the subsidence rate became greater than that of sedimentation; and during sequences 2 and 3 the sedimentation rate was slightly greater than subsidence, seen mainly in the PPFVarea.

The rising of the mountains varied in rate, roughly in accordance with the subsidence in the Granada basin. The rate reached a maximum in the lateTortonian, diminished in the Messinian and further diminished in the Pliocene.

The formation of the Granada basin can thus be seen as part of the morphogenetic and neotectonic evolution of the Betic Cordillera from the late Miocene to the present and as a corollary, we propose that the mechanism of subsidence in Granada basin and the coeval uplifting of the surroundings relief, mainly Sierra Nevada, was consequence of faulting induced by crustal stretching subsequently to a period of tectonic denudation in a process in which a near $\mathrm{N}-\mathrm{S}$ compression combined with an important and approximately perpendicular crustal extension.

\section{ACKNOWLEDGEMENTS}

We would like to thank Chevron Oil Company and Dr J. Morales for providing several seismic profiles, Dr J. Galindo-Zaldivar for his help in digitizing data, and Dr J.A. Martín-Pérez for the determination of the foraminifera and calcareous nannoplankton; also to Drs J. Carlos Braga from the University of Granada and P. Friend from Cambridge University for their useful suggestions for improving the manuscript. Our thanks to M. Pérez Arlucea from Vigo University, G. Postma from Utrecht University, M. Marzo from the University of Barcelona, and to Dr A. Hartley and Dr P. Van der Beek for their criticism and very helpful comments. This study received funding through projects: CGL2004-03333/BTE and CGL2004-01636 of the DGESIC, and the RNM 0163 and RNM 217 groups of the Junta de Andalucía.

\section{REFERENCES}

Allen, P. \& Allen, J.R. (1990) Basins Analysis Principles and Applications. Blackwell Scientific Publications, Oxford, London, 451pp.

Balanyá, J.C. \& García-DueÑas, V. (1987) Les directions structurales dans le Domaine d'Alboran de parts et d'outre du Détroit de Gibraltar. C. R. Acad. Sci. Paris, 304, 929-933.

Banda, E., Gallart, J., García-Dueñas, V., Dañobeitia, J.J. \& MAKRIS, J. (1993) Lateral variation of the crust in the Iberian Peninsula - new evidence from the Betic Cordillera. Tectonophysics, 221, 53-66.

Berggren, W.A., Kent, D.V., Swisher, C.C. \& Auby, M.P. (1995) Revised cenozoic geochronology and chronostratigraphy. SEMP Spec. Publ., 54, 129-212.

Braga, J., Martín, J. \& Alcalá, B. (1999) Coral reef in coarse-terrigenous sedimentary environments (Upper Tortonian, Granada Basin, southern Spain). Sediment. Geol., 66, 135-150.

Braga, J., Martín, J. \& Quesada, C. (2003) Patterns and average rates of late Neogene-Recent uplift of the Betic Cordillera, SE Spain. Geomorphology, 50, 3-26.

Buforn, E., Sanz de Galdeano, C. \& Udías, A. (1995) Seismotectonics of the Ibero-Maghrebian region. Tectonophysics, 248, 247-261.

Cloetingh, S., Vanderbeek, P.A., Vanrees, D., Roep, T.B., Biermann, C. \& Stephenson, R.A. (1992) Flexural Interaction and the dynamics of Neogene extensional basin formation in the Alborán-Betic region. Geo-Mar. Lett., 12, 66-75.

Dabrio, C., García-Yebra, R., González Donoso, J.M. \& Vera, J.A. (1972) Turbiditas asociadas a evaporitas (Mioceno, La Malá, Depresión de Granada. Cuad. Geol., 3, 139-164.

Dabrio, C. \& Fernández, J. (1986) Depósitos de ríos trenzados conglomeráticos plio-pleistocénicos de la Depresión de Granada. Cuad. Geol. Ibér., 10, 31-53.

Dabrio, C., Fernández, J., Peña, J.A., Ruiz-Bustos, A. \& Sanz de Galdeano, C. (1978) Interprétation sédimentaire des matériaux néogènes du bord nord-est du basin de Grenade (Espagne). C.R. Som. Soc. Géol Fr., 121-123.

Dinarés, J., Ortí, F., Playá, I. \& Rosell, L. (1999) Paleomagnetic chronology of the evaporitic sedimentation in the Neogene Fortuna Basin (SE Spain): early restriction preceding the "Messinian Salinity Crisis". Palaeogeogr. Palaeoclimatol. Palaeoecol., 154, 161-178.

Durand-Delga, M. (1980) La Méditerranée occidentale: étape de sa genèse et problèmes structuraux liés à celle-ci. Livre Jubilaire de la Soc. géol. de France, 1830-1980. Mem. H. Sér. S.G.F., 10, 203-224.

Estévez, A., López-Garrido, A.C., Rodríguez-Fernández, J., Alberdi, M.T. \& Ruiz-Bustos, A. (1982) On the Miocene-Pliocene age of the detrital-series from the western part of the Granada Basin (South Spain). C. R. Acad. Sci. Sér. Il, 294, $1187-1190$.

Fernández, J. \& Rodríguez-Fernández, J. (1991) Facies evolution of nearshore marine clastic deposits during the tortonian transgression - Granada Basin, Betic Cordilleras, Spain. Sediment. Geol., 71, 5-21.

Galindo-Zaldívar, J., Gil, A.J., Borque, M.J., González Lodeiro, F., Jabaloy, A., Marín-Lechado, C., Ruano, P. \& Sanz de Galdeano, C. (2003) Active faulting in the internal zones of the central Betic Cordilleras (SE, Spain). 7. Geodyn., 36, 239-250. 
Galindo-Zaldívar, J., González-Lodeiro, F. \& Jabaloy, A. (1993) Stress and palaeostress in the Betic-Rif cordilleras (Miocene to the present). Tectonophysics, 227, 105-126.

Galindo-Zaldívar, J., Jabaloy, A., Serrano, I., Morales, J., González-Lodeiro, F. \& Torcal, F. (1999) Recent and present-day stresses in the Granada Basin (Betic Cordilleras): example of a late Miocene-present-day extensional basin in a convergent plate boundary. Tectonics, 18, 686-702.

Gansser, A. (1982) The morphogenic phase of mountain building. In: Mountain Building Processes (Ed by J.K. Hsü), pp. 221228. Academic Press, New York.

Garcés, M., Krijgsman, W. \& Agustí, J. (1998) Chronology of the late Turolian deposits of the Fortuna basin (SE Spain): implications for the Messinian evolution of the eastern Betics. Earth Planet. Sci. Lett., 163, 69-81.

García-Dueñas, V., Balanyá, J.C. \& Martínez-Martínez, J.M. (1992) Miocene extensional detachments in the outcropping basement of the northern Alborán Basin (Betics) and their tectonic implications. Geo-Mar. Lett., 12, 88-95.

GeEL, T. (1995) Oligocene to early Miocene tectono-sedimentary history of the Alicante region (SE Spain). Implication for western Mediterranean evolution. Basin Res., 7, 313-336.

Giménez, J., Surinach, E. \& Goula, X. (2000) Quantification of vertical movements in the eastern Betics (Spain) by comparing levelling data. Tectonophysics, 317, 237-258.

Hanne, D., White, N. \& Lonergan, L. (2003) Subsidence analyses from the Betic Cordillera, southeast Spain. Basin Res., 15, $1-21$.

Hardenbol, J., Thierry, J., Farley, M.B., Jacquin, T., GraCiansky, P.C. \& Vail, P. (1998) Mesozoic and cenozoic sequence chronostratigraphic chart. In: Mesozoic and Cenozoic Sequence Stratigraphy of Europen Basins (Ed by P.C. Graciansky, J. Hardenbol, T. Jacquin \& P. Vail), SEMP Spec. Publ., 60.

Iaccarino, S. (1985) Mediterranean Miocene and Pliocene planctonik foraminifera. In: Plankton Stratigraphy (Ed by H.M. Bolli, J.B. Saunders \& K. Perch-Nielsen), pp. 283-314. Cambridge University Press, Cambridge.

Janssen, M.E., Torné, M., Cloetingh, S. \& Banda, E. (1993) Pliocene uplift of the eastern Iberian margin: inferences from quantitative modelling of the Valencia Trough. Earth Planet. Sci. Lett., 119, 585-597.

Johnson, C. (1993) Contrasted thermal histories of different nape complexes in S.E. Spain: evidence for complex crustal extension. In: Late Orogenic Extension in Mountain Belts (Ed by BRGM Éditions), document 219, p. 103, Montpellier, France.

Johnson, C. (1997) Resolving denudational histories in orogenic belts with apatite fission-track thermochronology and structural data: an example from southern Spain. Geology, 25, 623626.

Johnson, C., Harbury, N. \& Hurford, A.J. (1997) The role of extension in the Miocene denudation of the Nevado-Filábride, Betic Cordillera (SE Spain). Tectonics, 16, 189-204.

Monié, P., Galindo-Zaldívar, J., Lodeiro, F.G., Goffe, B. \& JABALOY, A. (1991) Ar-40/Ar-39 geochronology of alpine tectonism in the Betic Cordilleras (Southern Spain). 7. Geol. Soc., 148, 289-297.

Montenat, C., Rodríguez-Fernández, J., Ott d'Estevou, P. \& Sanz De Galdeano, C. (1990) Geodynamic evolution of the Betic Neogene intramontane basins (S and SE Spain). In: Iberian Neogene Basins. Mem. Spe. 2 (Ed by J. Agusti, R. Doménech \& R. Julià), pp. 6-59. Institut de Paleontología Miguel Crusafonf, Sabadell.
Morales, J., Vidal, F., de Miguel, F., Alguacil, G., Posadas, A.M., Ibáñez, J.M., GuZmán, A. \& GuiraO, J.M. (1990) Basement structure of the Granada basin, Betic Cordilleras, southern Spain. Tectonophysics, 177, 337-348.

OKADA, H. \& BuKry, D. (1980) Supplementary modification and introduction of code numbers to the low latitude cocolith biostratigraphic zonation (Bukry, 1973, 1975). Mar. Micropaleontol., $5,321-325$.

Platt, J. \& Whitehouse, M.J. (1999) Early Miocene high-temperature metamorphism exhumation in the Betic Cordillera (Spain): evidence from U-Pb zircon age. Earth Planet. Sci. Lett., 171, 591-605.

Rodríguez-Fernández， J. (1982) El Mioceno del Sector Central de las Cordilleras Béticas. PhD Thesis, Granada, $224 \mathrm{pp}$.

Rodríguez-Fernández, J. \& Comas, M.C. (1999) The role of the strike-slip tectonics in the evolution of the Alborán Sea, Western Mediterranean. 6Th International Congress of the Brazilian Geophysical Society, Rio de Janeiro, pp. 1-3.

Rodríguez-Fernández, J., Comas, M.C., Soria, J., MartínPérez, J.A. \& Soto, J.I. (1999) The sedimentary record of the Alborán Basin: attempt of correlation and subsidence analysis. In: Proceedings of the Ocean Drilling Program, Scientific Results (Ed by R. Zahn, M.C. Comas \& A. Klaus). Vol. 61, pp. 69-76. College Station, Texas, EEUU Ocean Drilling Program.

Rodríguez-Fernández, J., Fernández, J., López-Garrido, A.C. \& Sanz de Galdeano, C. (1984) The Central Sector of the Betic Cordilleras, a realm situated betwen the Atlantic and Mediterranean domains during the upper Miocene. Ann. Geol. Pays. Hell., 32, 97-103.

Rodríguez-Fernández, J., Sanz de Galdeano, C. \& FernánDEZ, J. (1989) Genesis and evolution of the Granada Basin (Betic Cordillera, Spain). In: Proceedings of the International Symposium on Intermontane Basins; Geology and Resources (Ed by T. Theerapongs \& O. Prayote), pp. 294-305. Chiang Mai, Thailand.

Rodríguez-Fernández, J. \& Martín-Penela, A. (1993) Neogene evolution of the Campo de Dalias and the surrounding offshore areas - (Northeastern Alborán Sea). Geodyn. Acta, 6, 255-270.

Ruiz-Bustos, A. (2002) Características Climáticas y Estratigráficas de los Sedimentos continentales de la Cordilleras Bética durante el Plioceno a partir de las Faunas de Mamíferos. Pliocénica, 2, 44-64.

Ryan, W.B.F. (1976) Quantitative evaluation of the depth of the western Mediterranean before, during and the Late Miocene salinity crisis. Sedimentology, 23, 791-813.

Sanz de Galdeano, C. (1988) The fault system and the Neotectonic features of the Betic Cordilleras. In: Fifth E.G.T. Workshop "The Iberia Peninsula". Estoril (Ed By E. Banda \& V. Mendes), Eur. Sci. Found., 1, 99-109.

Sanz de Galdeano, C. (1990) Geologic evolution of the Betic Cordilleras in the western Mediterranean, Miocene to the present. Tectonophysics, 172, 107-119.

Sanz de Galdeano, C. \& Alfaro, P. (2004) Tectonic significance of the present relief of the Betic Cordillera. Geomorphology, 63, 178-190.

Sanz de Galdeano, C. \& López-Garrido, A.C. (1999) Nature and impact of the Neotectonic deformation in the western Sierra Nevada (Spain). Geomorphology, 30, 259-272. 
Sanz de Galdeano, C., Peláez, J.A. \& López, C. (2003) Seismic potentiality of the main active faults in the Granada Basin (south of Spain). Pure Appl. Geophys., 160, 1537-1556.

Sanz de Galdeano, C. \& Vera, J.A. (1992) Stratigraphic record and palaeogeographical context of the Neogene basins in the Betic Cordillera, Spain. Basin Res., 4, 21-36.

Sclater, J.G. \& Christie, P.A.F. (1980) Continental stretching and explanation of the post-mid-cretaceous subsidence of the North Sea basin. 7. Geophys. Res., 85, 3711-3739.

Soria, J.M., Alfaro, P., Fernandez, J. \& Viseras, C. (2001) Quantitative subsidence-uplift analysis of the Bajo Segura Basin (eastern Betic Cordillera, Spain): tectonic control on the stratigraphic architecture. Sediment. Geol., 140, 271-289.

Soria, J., Viseras, C. \& Fernández, J. (1998) Late Miocene-Pleistocene tectono-sedimentary evolution and subsidence history of the central Betic Cordillera (Spain): a case study in the Guadix intramontane basin. Geol. Mag., 135, $565-574$.

ten Veen, J.H. \& Postma, G. (1999a) Neogene tectonic and basin fill patterns in the Hellenic outer-arc (Crete, Greece). Basin Res., 11, 223-241. ten Veen, J.H. \& Postma, G. (1999b) Roll-Back controlled vertical movement of outer-arc basins of the Hellenic subduction zone (Crete, Greece). Basin Res., 11, 243-266.

Van Houten, F.B. (1981) The Odyssey of Molasse. In: Sedimentation and Tectonics in Alluvial Basins (Ed by A.D. Miall. Toronto. Geol. Assoc. Canada, Special Paper 23, 35-48.

Watts, A.B., Platt, J.P. \& Buhl, P. (1993) Tectonic evolution of the Alborán Sea basin. Basin Res., 5, 153-177.

Wiejermars, R., Roep, T., Van den Eeckhout, B., Postma, G. \& Kleverlaan, K. (1985) Uplift history of a Betic fold nape inferred from Neogene-Quaternary sedimentation and tectonics (in the Sierra Alhamilla and Almeria, Sorbas and Tabernas Basins of the Betic Cordilleras, SE Spain). Geol. Mijnbow, 64, 397-411.

Zahn, R., Comas, M.C. \& Klaus, A.), (eds) (1999) Science Results, 161Proceedings of ODP (Ocean Drilling Program). Collage Station, Texas.

Manuscript received 6 September 2004; Manuscript accepted 23 January 2006. 